\title{
Communicative culture of the future specialist of a technical university and his personal development in modern realities
}

\author{
Laysan Nigmatillina ${ }^{1 *[0000-0003-0100-2086]}$ \\ ${ }^{1}$ Kazan State University of Architecture and Engineering, 420043, Zelenaya st., Kazan, Russia
}

\begin{abstract}
The important characteristics of a person and activity of future specialist are not only the possession of information, of professional activity technologies, but also of communicative culture, which provides going beyond the regulatory activities, ability to create and transfer values, provide personal development and competitiveness on the labor market. Today, a low level of speech culture leads to a decrease in the general culture of young people and, as a result, is an obstacle to further career development in any field. The problem generally affects such industries as construction, architecture, design, as they are among the most demanded professions on the international labor markets.

Keywords: culture, communicative, technical university.
\end{abstract}

\section{Introduction}

This article is dedicated to different aspects of contemporary education. We should know if it increases the speech level of students during ordinary classes and lessons. How should we find problems in today's education and solve it as soon as possible? This article answers these questions.

\section{Methods}

As university workers we have a huge experience in giving lessons to students. And also we have an opportunity to listen to their position about contemporary communicative culture. We analyze statistics and make decisions about it. References helped us in having a theoretical basement of our statements in this research. Also there you can find an interesting try on comparing sphere of economics and culture which we find really nonstandard.

\footnotetext{
* Corresponding author: nigmatullinal1971@mail.ru
} 


\subsection{Purposes of today's education}

Purpose of today's education: reveal and by experiment examine pedagogical conditions for the effectiveness of the formation of the communicative culture of future specialists, graduates of technical university in the process of implementing a new generation of FSES.

Object of education: the formation of the communicative culture of future specialists, graduates of technical university in the process of implementing a new generation of FSES.

Subject of education: a set of pedagogical conditions for the formation of a communicative culture of future specialists, graduates of a technical university in the process of implementing a new generation of FSES [1, p.107]

The new social-economic conditions in Russia require a significant increase in the country's human resources potential based on the modernization of the teacher education system.

Education is a microeconomics of the country, where essentially all the industry and production characteristics determine the economic complex of the country. The specialist is still remaining the leading component in the system of economic space.

The design of education aimed at the creative self-development of its subject is becoming a new paradigm of pedagogy. Within this paradigm, a student is considered not only as an object of pedagogical influence, but also as a subject of independent cognitive activity in a changing social environment.

The purpose of education today is to prepare a competitive specialist, , to stimulate the development of a consistent practical attitude to knowledge among trainees, to develop needs for knowledge-transformations, polytechnic skills, knowledge-tools that allow them to gain social security, professional mobility, all-round competence, creative self-development skills [2, p.102]

Teaching such a creatively self-developing specialist, the activity of which appears to be complex and multifunctional is a long-term process, holistic, continuous process, focused on the formation of professionally significant personal qualities, creative abilities, knowledge, skills, adequate to the personal and qualification requirements of the specialist.[3, p.67]

\subsection{The problem of a traditional approach}

For a long time communications culture was considered as a set of norms, rules, regulating the communication process. This, definitely, important specifications, but they cannot allow us to imagine this phenomenon under study in full inconsistency and diversity of its structural and functional components. This approach keeps dangerous reassessment of the role of communication practice and experience. In solving the problem of formation of a communicative culture it is important not only to assimilate the fact of cultural and pedagogical heritage but also to include the teacher as a subject of culture (as a carrier of a reflexive-conscious attitude to the world of values) in the process of innovative activities for the creation and implementation of pedagogical innovations.

The analysis of pedagogical practice shows that the communicative culture of students is mainly formed spontaneously, as if it is an accompanying, secondary task of their professional preparation. This is explained by the insufficient level of scientific and methodological support for the purposeful formation of the communicative culture of the future primary school teacher in the context of the implementation of the new generation of the Federal State Educational Standard.

The particular problem of the formation of the communicative culture of future specialists is represented in the conditions of bilingualism in national regions, such as the Republic of Tatarstan, where professional training should include not only specific skills 
and skills of speech behavior, but also meet the peculiarities of the modern style of bilingual communication. Just the high level of development of the communicative culture of the future primary school teacher can guarantee the effective performance of their professional functions in the situation of communication with students of different nationalities [4, p.45] [5] [6, p.40] [7, p.133]

In the pedagogical and psychological sciences, the philosophical and methodological aspects of the formation of communicative culture were considered in the works of V. T. Lisovsky, V. A. Razumny, V. N. Shubkin, and A. G. Kharchev. The socio-psychological aspect of the formation of communicative culture is reflected in the studies of A. A. Bodalev, A. N. Leontiev, B. F. Lomov, M. I. Lisina, L. A. Sugai, M. R. Hammer, etc [8, p.40], [9, p. 47] [10, p. 327]

It is obvious that at present there is an objective need in conducting new research to identify the pedagogical conditions for the formation of the communicative culture of students in the process of the new generation of FSES [11].

\subsection{The main contradictions}

Thus, after analyzing the scientific literature and real pedagogical practice, a number of contradictions are revealed:

- between the social necessity and the objective need of educational practice in the purposeful formation of the communicative culture of future specialists and the insufficient level of theoretical and methodological development of this problem, taking into account the features of the new generation of Federal State Educational Standards.

- the necessity to form a communicative culture of students, on the one hand, and the lack of scientifically based pedagogical conditions for its formation, taking into account the features of the new generation of FSES, on the other hand [12, p. 38] [13, p. 251].

\subsection{What is culture?}

Let's consider the specific features of the orientation of education to the formation of the communicative culture of the individual as an integrative indicator of a modern competent specialist $[14$, p. 116].

The concept of «culture» is translated from Latin as cultivation, processing, and sometimes also as «education, development». The concept itself is firmly embedded in the lexicon of sociologists, psychologists, publicists, politicians, economists, in the casual speech of the general population in the X1X and especially the XX century. But already in Ancient Rome, Cicero, identifying the culture of the soul and the culture of the body, considered them as the development of mental abilities that must be respected and revered. In Plato's definition, culture is a guide to changing the whole person in his essence.

The separation of professional culture as one of the properties of a group of people belonging to the same profession is the result of the division of labor, which leads to the separation of types of special activities. Professional activity as a socio-cultural phenomenon has a complex structure, including the goal, objectives, subject, means, methods, and result.

High level of professional culture of a specialist is characterized by a developed ability to solve professional problems, i.e., developed professional thinking and consciousness. Professional culture is a certain degree of mastery of a person's techniques and ways of solving professional problems $[15, \mathrm{p} .42]$. 


\subsection{A communicative culture}

A special place in the professional culture is occupied by the communicative culture. The communicative culture of a specialist determines the historically achievable measure of its impact on the development of the student's personality. The success of the interaction between the educational process and students is determined by the level of communicative culture (the culture of the teacher's communicative activity) as an obligatory component of the holistic pedagogical process, the means and conditions for the implementation of all functions and types of professional activity [16, p. 400].

The structure of the communicative culture of the future specialist is understood as reflecting the interests of those parties whose needs are met in the process of professional communication.

Based on the opinion of O. P. Sokolova : "The communicative culture of an individual is defined as a system of knowledge and skills, so as to naturally implement them in business and emotional communication» and, agreeing with A.V. Mudrik, the communicative culture as a component of the professional culture of the future specialist is a system of knowledge, norms, values and behaviors accepted in the society and the ability to organically implement them in business and emotional communication.

\subsection{Dependence of CC and an education system}

The communicative culture of the future specialist determines the potential of the education system, the historically achievable measure of its impact on the development of the student's personality. The success of the interaction of the subjects of the educational process is determined by the level of communicative culture as an obligatory component of the whole process, the means and conditions for the implementation of all functions and types of professional activity.

The systematization of professional and general competencies of future specialists in the content of subjects of the general humanitarian and socio-economic cycles: philosophy, psychology of communication, history, Russian language, literature studies is carried out in the context of the communicative component in the process of implementing the new generation of the Federal State Educational Standard [17, p. 203].

In modern conditions, the important characteristics of a personality and activity of a specialist are not only the possession of information, technologies of professional activity, but also the communicative culture that provides a way beyond the limits of normative activity, the ability to create and transmit values, to determine personal development, guarantees high competitiveness.

Methods: description of the main annual events held at KSUAE.

Table 1. Stages and terms of implementation.

\begin{tabular}{|c|l|l|l|}
\hline № & Stages of a realization & Name of events & $\begin{array}{l}\text { Terms } \\
\text { implementation }\end{array}$ \\
\hline 1 & Collection of creative works & & September - March \\
\hline 2 & $\begin{array}{l}\text { Integration with the creative } \\
\text { intelligentsia by literary } \\
\text { associations, magazines by } \\
\text { contemporary writers }\end{array}$ & $\begin{array}{l}\text { Trips, meetings, } \\
\text { negotiations at different } \\
\text { levels in order to agree on } \\
\text { the upcoming event }\end{array}$ & September -March \\
\hline 3 & $\begin{array}{l}\text { Compilation and } \\
\text { systematization of works in a } \\
\text { collection }\end{array}$ & $\begin{array}{l}\text { Readers conference } \\
\text { «Lyric engineers» }\end{array}$ & March \\
\hline
\end{tabular}




\begin{tabular}{|c|l|l|l|}
\hline 4 & $\begin{array}{l}\text { Publication of a collection of a } \\
\text { creative works for the } \\
\text { conference }\end{array}$ & $\begin{array}{l}\text { Readers conference } \\
\text { «Lyric engineers» }\end{array}$ & April \\
\hline 5 & $\begin{array}{l}\text { Publication of articles covering } \\
\text { the held event }\end{array}$ & August \\
\hline
\end{tabular}

\section{Results}

Results: Today, a low level of speech culture leads to a decrease in the general culture of young people and, as a result, is an obstacle to further career development in any field. The problem generally affects such industries as construction, architecture, design, as they are among the most demanded professions on the international labor markets.

E. G. internet has an influence on a speech culture as it affects the economics and other spheres of social life. We can draw a parallel between speech and economics. One article says that ehe success of the implementation of the modern economy is largely determined by the introduction of information technologies. At the same time, the economy is acutely aware of the lack of time and resources, so, especially the consumer seeks to save both money and time. Communication culture behaves in the same way. In the rapidly developing Internet space, everyone wants to save time, so speech suffers changes and becomes less expressive and colorful. And there we have a special need to fix it [18, p. 45]

Also the problem of the formation of the communicative culture of future specialists is especially difficult in the conditions of bilingualism in national regions, such as the Republic of Tatarstan, where professional training should include not only specific skills and abilities of verbal behavior, but also respond to the features of the modern style of bilingual communication.

As we can read in another economical article: «One of the most important tasks facing the Russian construction industry is to improve the quality of construction work and services» $[19$, p. 38]. And we can't agree with that, because we as native speakers should improve the quality of communicative culture. This is our monumental building that will also stand for ages. Our children will see it and honor it.

\section{The project and its stages}

The project involves the conduct and publication of creative works for the past period. Also, this approach is taken into account when preparing and holding annual readers conferences, where famous writers, poets, journalists, public figures of the Republic of Tatarstan are invited.

According to the theme of conferences in different years, the university was visited by: Albina Absolyamova, editor of the Idel magazine, poet Alena Karimova, poet Zubarzhat Arslanova, pianist, poet Salavat Yuzeev, director Maxim Nekrasov, young poet Galina Zainullina, prose writer, editor of Idel magazine and many others. Meetings of students with masters of words who have made a contribution to the development of the culture of the Republic of Tatarstan are positively reflected not only not in the all-round development of youth, but also lay the basic universal to the formation of a communicative culture.

At the first stage (September), the topic of the future conference is determined, its goal and objectives are clarified, the stage of preparedness of students is revealed, that is the level of school preparation. In connection with this, scientific and fictional literature is studied, the readers experience is analyzed and summarized, and a pilot study is carried out in the form of writing creative works: «again very much», «I sit at my desk...», «there is in the initial autumn...», «one student day...». 
At the second stage (October-November), experimental work is carried out, on the basis of which the topic of the conference is clarified, the best creative works, reviews of read books are collected, the testing of tools that are involved in the process of forming the communicative culture of future civil engineers is carried out, the primary processing of experimental data in the form of compiling the text of the future layout of the collection.

At the third stage (December), the results of the experimental work are summarized, the layout of the collection is made out, the reading and discussion of fiction continues through the introduction of classes in the Russian language and speech culture of readers ' conferences. Based on the reviews of books read and discussions of the works of outstanding masters of the word who received the Nobel Prize, a textbook on the Russian language and speech culture «Nobel Laureates in literature» was formed. The manual includes adapted texts that are not only of interest from the point of view of literature, but also of universal significance.

\section{Recommendations}

The practical significance of the method lies in the fact that its conclusions and recommendations can be used in the practice of teaching the Russian language and speech culture in a technical university. It is determined by the introduction into the educational process of the model of formation of the communicative culture of future civil engineers; preparation and holding of monthly and final readers ' conferences with the involvement of professional masters of the word; collection of material, layout, editing of a collection of creative works of students; development and publication of a manual for students; creation of variable courses aimed at solving the problems of forming the communicative culture of future technical specialists.

The main theoretical positions and results are discussed and published at international scientific and practical conferences, interregional, Republican and All-Russian seminars, in the youth magazine «Idel». The results of the study were discussed at the meetings of the Department of Foreign Languages of KSUAE.

The conclusions were presented in the creative works of the students and presented in the form of theses at the discussion council in the editorial office of the journal «Idel» and subsequently published.

\section{Conclusions}

In conclusion, we want to show you the results of a survey conducted among students. It showed that the number of students who have reached a high level of formation of communicative culture has increased.

In the modern global information society the role of education as the main factor of the development of a person and his/her spiritual moral qualities, creative potential and culture is increasing. Therefore, education possesses socio-cultural and economic potential of the global information society affecting directly its development [20, p. 144] 
Table 2. Diagnosis of level formation. Communication culture of the future engineer at the final stage.

\begin{tabular}{|c|c|c|c|c|}
\hline \multirow{2}{*}{$\begin{array}{l}\text { The content of the } \\
\text { components of the structure } \\
\text { of the future teacher's } \\
\text { communicative culture. }\end{array}$} & \multicolumn{2}{|c|}{ Control groups } & \multicolumn{2}{|c|}{ Experimental groups } \\
\hline & PG1-7 & AP1-5 & PG1-7 & AP1-5 \\
\hline \multicolumn{5}{|c|}{ The emotional-value component. } \\
\hline \multicolumn{5}{|c|}{$\begin{array}{l}\text { a) Directed awareness of the available personal resources that contribute to the formation of a cultural } \\
\text { lifestyle and highly effective behavior: }\end{array}$} \\
\hline $\begin{array}{l}\text { 1. I have my own formulated } \\
\text { system of cultural values, } \\
\text { goals and attitudes }\end{array}$ & 1.3 & 1.1 & 1.3 & 0.9 \\
\hline $\begin{array}{l}\text { 2. I have the ability to make } \\
\text { my own choices }\end{array}$ & 0.9 & 1.1 & 1.0 & 1.4 \\
\hline 3. I can control my speech & 0.8 & 0.3 & 1.1 & 0.9 \\
\hline $\begin{array}{l}\text { 4. I know how to } \\
\text { communicate } \\
\text { individuals engaged } \\
\text { business }\end{array}$ & 0.5 & 0.4 & 0.6 & 0.7 \\
\hline $\begin{array}{l}\text { 5. I understand their behavior } \\
\text { and prospects }\end{array}$ & 1.3 & 1.2 & 1.5 & 1.3 \\
\hline \multicolumn{5}{|c|}{ b) Development of personal resources that contribute to the formation of a communicative culture } \\
\hline $\begin{array}{l}\text { 1. I can adequately assess } \\
\text { problematic situations and } \\
\text { resolve personal problems }\end{array}$ & 0.8 & 0.8 & 0.9 & 1.1 \\
\hline $\begin{array}{l}\text { 2. I manage myself and can } \\
\text { change myself }\end{array}$ & 0.4 & 0.4 & 0.8 & 0.8 \\
\hline $\begin{array}{l}\text { 3. I know how to set short- } \\
\text { term and long-term goals and } \\
\text { achieve them }\end{array}$ & 0.4 & 0.4 & 0.9 & 0.7 \\
\hline $\begin{array}{l}\text { 4. I can control my behavior } \\
\text { and change my life }\end{array}$ & 0.8 & 0.8 & 0.9 & 1.1 \\
\hline $\begin{array}{l}\text { 5. I can be aware of what is } \\
\text { happening to me and why, } \\
\text { analyze my own state }\end{array}$ & 0.7 & 0.8 & 0.8 & 0.9 \\
\hline $\begin{array}{l}\text { 6. I can empathize with } \\
\text { others and understand them }\end{array}$ & 1 & 1.1 & 1.3 & 1.5 \\
\hline $\begin{array}{l}\text { 7. I understand the motives } \\
\text { and prospects of their } \\
\text { behavior }\end{array}$ & 1.3 & 1.3 & 1.4 & 1.5 \\
\hline $\begin{array}{l}\text { 8. I have the skills of } \\
\text { listening, dialogue, conflict } \\
\text { resolution, } \\
\text { feelings, and } \begin{array}{r}\text { making } \\
\text { decisions }\end{array}\end{array}$ & 1 & 0.9 & 1.5 & 1.3 \\
\hline $\begin{array}{l}\text { 9. I can accept and provide } \\
\text { psychological and social } \\
\text { support to others }\end{array}$ & 0.8 & 0.6 & 1.4 & 1.5 \\
\hline \multicolumn{5}{|c|}{ Motivational component } \\
\hline $\begin{array}{l}\text { 1. I understand the } \\
\text { importance } \\
\text { communication skills } \\
\text { 2. I have a need for the } \\
\text { development of a } \\
\text { communication culture }\end{array}$ & 0.4 & 0.5 & 0.4 & 0.5 \\
\hline
\end{tabular}


3. I want to have the skills to search for information and use the resources of libraries and the internet 4. I want to be able to build logical reasoning, including the establishment of causeand-effect relationships.

5. I have the skills of responsible behavior

6. I have the skills to extract essential information from various types of texts.

7. I have a need to improve my communication culture.

1. I have a holistic understanding of the role of man in economic theory scientific methods about the role of speech in the psychophysical

development of the individual

3.I know the basic functions

4. I can formulate my own opinion and position

5. I can negotiate and come to a common agreement for the organization of my own activities and cooperation with a partner

6. I can ask questions about the activities and cooperation with the partner 7. I can adequately use speech to plan and regulate my activities

8. I can adequately use speech tools to effectively solve a variety of communication tasks

9. I can transmit the necessary information to the partner

10. I have the skills to analyze economic situations and solve economic problems
2. I understand modern

0.2

0.1

Cognitive component

Communication and activity component

a) Development of personal professional resources

1. I have a culture of thinking; I know its general laws of communication.

2. I can correctly (logically) formalize the results of educational, scientific and industrial activities in oral
0.6

0.5

0.6
0.7

$-0.1$

$-0.5$

0.6 
and written speech

3. I have knowledge and a high level of personal health 4. I consider myself responsible for my life, the lives of my loved ones, and I also have professional responsibility

5. I have an adequate selfesteem

6. I know how to make a choice

7. I can take into account different opinions and interests, justify my own position

c) Development of strategies and skills of high-functional behavior

1. I apply the results of modern sociological research on the problem of educational reforms

2. I understand the relativity of opinions and approaches to solving the problem

3. I can argue my position and coordinate it from the position of partners in cooperation in developing a common opinion in my own activities

4. I am able to acquire new knowledge using modern information and educational technologies

5. I have modern theoretical knowledge about social partnership

6. I can effectively resolve conflicts based on the interests and positions of all participants.

7. I accept the possibility of people having different points of view and focus on the position of the partner in communication and interaction

8. I can determine the status of a person in a group

9. I can evaluate the totality and associations of an individual

10. I can consciously and arbitrarily build a speech statement in oral and written form

11. I can establish analogies

\begin{tabular}{l|l|}
-0.1 & -0.3 \\
-0.2 & -0.1 \\
-0.1 & -0.2 \\
-0.7 & -0.6 \\
-0.1 & -0.3
\end{tabular}


12. I have the skills to organize the workplace and distribute working time

13. I know how to make professional decisions taking into account the requirements of ethics

14. I am able to conduct pedagogical activities to teach students knowledge about the structure and functions of the body, change them under the conditions of adverse environmental factors, infections and hypodynamia 15. I teach students to evaluate their physical condition, identify harmful factors that negatively affect health, use physical activity, folk remedies to preserve health

16. I know how to influence relationships between people and situations in a small group

17. I know how to work in an informal environment

18. I know the norms of family, labor, and housing legislation regulating the protection of motherhood and childhood, and the rights of minors.

I have certain professional skills:

19. The ability to enter the world of teenagers without breaking the boundaries of the individual

20. The ability to create a safe and supportive environment

21. The ability to use the nonverbal component of communication

22. I know the technique of speech

23. I have the skills of public speaking

24. Is able to use professional-oriented

rhetoric

According to the results of the formative stage, the number of students who have reached a high level of formation of communicative culture has increased.

0.6

$-0.6$

0.6 
Table 3. Distribution of students of control and experimental groups according to the levels of formation of communicative culture at the final stage.

\begin{tabular}{|c|c|c|c|c|}
\hline Direction & \multicolumn{2}{|c|}{ PG } & \multicolumn{2}{c|}{ AP } \\
\hline Groups & control & experimental & control & experimental \\
\hline High & 19 & 30 & 17 & 26 \\
\hline Average & 46 & 55 & 44 & 54 \\
\hline Low & 35 & 5 & 39 & 20 \\
\hline
\end{tabular}

\section{References}

1. I. A. Kolesnikova, Humanitarization of continuing education - one of the directions of modernization Russian Society, Social-Gum. Knowledge: science education, Ministry of education RF, 1, 107 (2004)

2. V. I. Andreev, Business rhetoric: a practical course of training and oratorical skills, Narodnoe obrazovanie, 5, 102 (1995)

3. V. I. Andreev, Pedagogy of creative development, Kazan University Publishing House, 1, 67 (1996)

4. I. Semenov, Language and ethnic conflict, M. Karnegi centre Gendalf, 45 (2001)

5. O. N. Alekseeva, Opinion of users about the communicative culture of service in the Kemerovo Regional Scientific Library named after V. D. Fedorov, Library life of Kuzbass, 2, 116 (2007)

6. M. G. Akhmetzyanov, Formation of artistic and aesthetic orientations of high school students in the process of mastering the course of Russian literature, 38 (1995)

7. V. I. Baidenko, Competence-based approach to the design of State Educational Standards of higher professional education, 251 (2005)

8. L. A. Sugay, The terms culture, civilization and enlightenment in Russia of the XIXearly XX century, Works of GASK, 2, 39-53 (2000)

9. V. N. Naumchik, M. A. Pazdnikov, Social pedagogy: a manual for teachers, educators, students, undergraduates, postgraduates of pedagogical higher educational institutions, 400 (2005)

10. A. J. Antsupov, A. I. Shipilov, Conflictology, UNITY, 221 (2000)

11. I. E. Vorozheikin, I. Kibanov, D. K. Zakharov, Classification of conflicts, Conflictology, 47 (2004)

12. S. V. Sokolov, Social conflictology: studies. manual for universities, UNITI-Dana, 1, 327 (2002)

13. M. R. Hammer., The Intercultural Conflict Style Inventory: Interpretive Guide, Hammer Consulting, 1-2 (2003)

14. A. S. Lather, Sh. Jain, A. D. Shukla, Cross Cultural Conflict Resolution Styles: An Extensive, Asian Journal of Managemet Res, 1, 130-146 (2011)

15. G. R. Weaver, Communication, and Conflict: Readings in Intercultural, Pearson Pub, 1, 563 (2000)

16. Ur Penny, A Course in Language Teaching, CUP, 1, 203 (1996)

17. FSES SPO, Order of the Ministry of Education and Science of the Russian Federation, 535 (2009)

18. A. I. Romanova, E. V. Ilyina, A. I. Rakhmatullin, Formation and transformation of capital in the market of information services in the regional economy, Bulletin of Economics, Law and Sociology, 1, 45-50 (2015) 
19. A. I. Romanova, E. R. Muharramova, Akhmetov, Dentification of the crisis situation at the enterprises of the construction services market, Sh. R. INGECON Bulletin. Series: Economics, 6, 157-162 (2010)

20. E .I. Medved, Ch. B. Daletsky, T. L. Khudyakova, S. P. Kulikov, L. V. Shukshina, R. S. Khammatova, O. V. Shabanova, Education and upbringing as socio-cultural development factors of contemporary society, International Journal of Applied Exercise Physiology, 2.1, 598-603 (2019) DOI: 10.7596/taksad.v8i1.2055 